\title{
KAJIAN MODEL ESTIMASI VOLUME LIMPASAN PERMUKAAN, DEBIT PUNCAK ALIRAN, DAN EROSI TANAH DENGAN MODEL SOIL CONSERVATION SERVICE (SCS), RASIONAL DAN MODIFIED UNIVERSAL SOIL LOSS EQUATION (MUSLE) (Studi Kasus di DAS Keduang, Wonogiri)
}

\author{
Ugro Hari Murtiono \\ Kelompok Peneliti Konservai Tanah dan Air (KTA) Balai \\ Penelitian Kehutanan Solo \\ Jl. Jend. A. Yani - Pabelan, Kartasura \\ Po Box 295 Surakarta 57102 \\ E-mail: ugrohari@yahoo.com
}

\begin{abstract}
Cydrologic modelling has been developing and it is usefull for basic data in managing water resources. The aim of the reseach is to estimate volume runoff, maximum discharge, and soil erosion with SCS, Rational, and MUSLE models on Keduang Watershed. Explain the data analysis, and flow to get the data. SCS parameters model use are: runoff, rainfall, deferent between rainfall runoff. The deferent rainfall between runoff relationship kurva Runoff Coefisient (Curve Nunmber/CN). This Coefisient connected with Soil Hydrology Group (antecedent moisture content/AMC), landuse, and cultivation method. Rational parameters model use are : runoff coefisient, soil type, slope, land cover, rainfall intensity, and watershed areas. MUSLE parameters model use are: rainfall erosifity (RM), soil erodibility (K), slope length (L), slope (S), land cover (C), and soil conservation practice (P). The result shows that the conservation service models be applied Keduang Watershed, Wonogiri is over estimed abaut $29.54 \%$, Rational model is over estimed abaut 49,96\%, and MUSLE model is over estimed abaut $48,47 \%$.
\end{abstract}

Keywords: bydrologycal models, estimate volume runoff, maximum discharge, and soil erosion, Soil Conservation Model (SCS), Rational models, and MUSLE models.

\section{PENDAHULUAN}

Salah satu program perencanaan pengelolaan DAS adalah perlu diketahuinya lebih dahulu kondisi hidrologi setempat. Namun demikian sebagian besar DAS yang akan direncanakan pengelolaan DASnya belum tersedia data hidrologi yang cukup memadai, untuk mengatasi masalah ini diperlukan suatu pendekatan melalui pemodelan hidrologi yang sesuai dengan kondisi biofisik sub DAS/DAS tersebut, hasil pemodelan tersebut diharapkan dapat diterapkan pada sub DAS/DAS yang mempu- nyai kemiripan kondisi biofisik. Dengan adanya model hidrologi yang sesuai maka karakterisasi dan evaluasi sub DAS/DAS tersebut dapat dengan mudah dilakukan.

Pemodelan hidrologi sudah diterapkan sejak lama. Prediksi debit maksimum (metode rasional) yang berdasarkan pada curah hujan, luas DAS, dan karakteristik daerah aliran sungai telah diperkenalkan pada tahun 1850 oleh Mulvaney (Fleming. 1979). Crawford dan Linsley (1960) memperkenalkan model Stanford untuk memprediksi "streamflow "dan sedimen dari DAS. 
Model-model hidrologi sebagian besar dikembangkan di daerah temperate, hanya sedikit yang dikembangkan di daerah tropis, padahal daerah tropis juga sangat memerlukan adanya model hidrologi. Model hidrologi yang dikembangkan di daerah temperate belum tentu sesuai bila diterapkan di daerah tropis karena selain perbedaan iklim juga perbedaan tanah dan vegetasi penutupnya.

Struktur model hidrologi didasarkan pada proses-proses yang ada dalam siklus hidrologi. Proses-proses tersebut mulai dari hujan, intersepsi, evapotranspirasi, infiltrasi, overlandflow, sub surface flow, perkolation, groundwater storage, ground water flow, sampai hasil air. Untuk itu perlu dikaji model-model hidrologi khususnya pada kawasan hutan dan non hutan yang dapat diterapkan dan dikembangkan di Indonesia.

Manfaat hasil analisis data hidrologi dewasa ini semakin dirasakan, bahkan selalu diperlukan sebagai data dasar bagi kegiatan yang menyangkut pengelolaan sumberdaya air DAS. Pada umumnya ada 3 (tiga) tahap dalam analisis hidrologi yaitu diawali dengan dengan mengadakan pengukuran terhadap fenomena hidrologi, membuat korelasi diantara peubah yang diteliti, dan melakukan prediksi (Sharp dan Sawden, 1984). Analisis regresi dan korelasi sering kali digunakan untuk membuat suatu model hidrologi. Model hidrologi diusahakan sesederhana mungkin dalam arti model tersebut mudah digunakan, tanpa mengabaikan aspek ketelitian, dan model yang dihasilkan bersifat prediktif.

Suatu model hidrologi umumnya menggunakan satuan DAS sebagai satu kesatuan daerah penelitian. Dalam analisis respons DAS, DAS merupakan satu sistem hidrologi dimana terdapat hubungan yang sangat erat antara setiap masukan yang berupa hujan, proses hidrologi DAS, dan keluaran yang berupa debit sungai dan sedimen yang terangkut.

Setelah memperhatikan prosesproses hidrologi dalam suatu DAS, maka dapat disimpulkan bahwa distribusi curah hujan menjadi aliran langsung selain dipengaruhi oleh sifat fisik permukaan DAS, juga dipengaruhi oleh sifat-sifat hujannya. Mengingat bahwa hujan yang terjadi di daerah beriklim tropika basah mempunyai variasi yang cukup besar menurut ruang dan waktu, maka kajian tentang hubungan hujan dan limpasan serta bagaimana pengaruhnya terhadap respons suatu DAS sangat diperlukan, mengingat pengukuran fenomena hidrologi terutama daerah-daerah yang tidak ada pencatatan data hidrologinya baik karena keterbatasan dana maupun sumberdaya manusianya, maka diperlukan suatu model korelasi diantara peubah, sehingga dengan adanya suatu model maka dapat dikurangi pengukuran fenomena hidrologi tersebut secara langsung.

Dalam pembuatan model diperlu-kan data yang lengkap dan akurat, sehingga hasil model dapat diterapkan pada daerah yang mempunyai kemiripan kondisi biofisik maupun sosial ekonominya. Dalam kajian ini hanya akan diuji pada model empiris yang merupakan salah satu bagian dari model deterministik. Model ini pada umumnya mempresentasikan hubungan dua atau lebih faktor-faktor hidrologi berdasarkan hasil pengamatan di laboratorium maupun lapangan. Model empiris biasanya berbentuk persamaan matematika berdasarkan informasi yang diperoleh dari hasil penelitian. 
Tujuan kajian ini adalah memprediksi volume limpasan permukaan, debit aliran puncak, dan erosi tanah dengan model SCS, Rational, dan MUSLE pada DAS Keduang.

Terjadinya erosi, banjir, kekeringan, pendangkalan sungai, waduk serta jaringan irigasi merupakan kenyataan bahwa sedemikian merosotnya kondisi hidroorologis dan makin buruknya mutu sumber daya alam di hampir semua wilayah Daerah Aliran Sungai (DAS) di Indonesia. Dengan kondisi yang demikian usaha -usaha pengelolaan wilayah DAS pada saat ini dirasakan kurang efektif dan kurang efisien, keadaan ini tercermin dengan masih belum terkendalinya banjir di musim hujan, terjadinya kekeringan dimusim kemarau dan menurunnya kualitas air. Banjir dan kekeringan disebabkan oleh tataguna sumberdaya tanah dan air belum sesuai dengan pengelolaan DAS yang baik, sedangkan makin menurunnya kualitas air merupakan akibat dari alokasi pembangunan di lingkungan pemukiman, industri, produksi.

Sampai saat ini pengelolaan DAS masih belum mencapai taraf yang dapat menjamin keseimbangan yang diperlukan dalam tiap-tiap DAS, yaitu: belum terwujudnya sinkronisasi program/rencana induk dari masing-masing kegiatan dalam satuan waktu dan tempat dari berbagai instansi yang terkait dalam pengelolaan DAS, sedangkan pengelolaan DAS yang ada sekarang adalah pengembangan rencana DAS dengan tekanan kepada Sub-sistem airnya saja, padahal sebenarnya yang diperlukan adalah konsep makro yang menyangkut total sistem (air, tanah, vegetasi dan masyarakat), yang tersusun dalam suatu preplanning, bukannya sebagai post-planning (Sudariyono, 1984).
Secara garis besar model hidrologi dapat dibagi menjadi 3 (tiga) bagian yaitu model deterministik, statistik, dan optimalisasi. Model deterministik dapat didefinisikan sebagai sebuah model baik empiris maupun konsepsual yang memperlakukan proses-proses hidrologi sebagai bagian dari sistem determinasi dengan tanpa membuat perwakilan dari proses-proses random yang mungkin muncul dalam sistem. Contoh dari model deterministik ini adalah Stanford Watershed Model. Model statistik memperhatikan hubungan antara proses-proses yang diarahkan ke teori statistik. Contoh dari model statistik ini adalah Co-axiial correlation model. Model optimum adalah model yang telah diberikan beberapa tujuan disatu sisi dan sisi lain telah diberikan beberapa hambatan. Kemudian model ini akan memberikan rencana yang paling bagus untuk kepuasan tujuan dengan hambatan-hambatan yang diberikan. Contoh model ini adalah model Fiering (1971).

Lebih jauh model deterministik dapat dibagi menjadi dua yaitu model empiris yang menekankan pada proses-proses komponen dan model konsepsual yang menekankan pada proses-proses terintegrasi. Model konsepsual ini masih dapat dibagi lagi menjadi 3 (tiga) bagian yaitu linear atau non linear, lumped atau distributed, dan sesaat atau kontinyu.

Model statistik dapat dibagi menjadi dua bagian yaitu model korelasi dan model stokastik. Model optimum dapat dibagi menjadi dua bagian yaitu analisis sistem dan "teori keputusan".

Pemodelan dapat memberikan beberapa kontribusi dalam pemahanan ilmiah (de coursey,1991 dalam de Roo, 1993). Model matematik yang lengkap dapat me- 
nyediakan garis besar konsep yang mungkin membantu tempat-tempat dimana pengetahuan tentang suatu hal masih kurang, dan mensimulasi ide-ide yang baru.

Pemodelan dapat membantu memberikan strategi dan dukungan taktis untuk sebuah program penelitian, memotivasi peneliti, dan mendorong kerjasama.

a. Model-model yang divalidasi dengan data dari DAS penelitian menyediakan sebuah mekanisme untuk transfer data dari daerah penelitian ke daerah dimana data akan dipakai.

b. Model hidrologi konsepsual adalah model hidrologi yang didasarkan pada proses-proses yang mempengaruhi response DAS. Model hidrologi konseptual diantaranya adalah model STANFORD. Model ini adalah salah satu model simulasi hidrologi dengan komputer yang paling awal. Model tersebut telah dikembangkan oleh Crawford dan Linsley pada tahun 1962. Model ini didasarkan pada penyederhanaan konsepsual dari proses-proses fisik overland flow, interflow, soil water storage, deep percolation, ground water storage, dan evapotranspirasi untuk memperkirakan streamflow dari data curah hujan. Model ini mensyaratkan kalibrasi untuk kondisi-kondisi spesifik DAS.

Limpasan permukaan adalah bagian dari curah hujan yang mengalir diatas permukaan tanah menuju sungai, danau dan lautan. Nilai limpasan permukaan yang penting untuk keperluan evaluasi DAS adalah kondisi volume limpasan permukaan yang terjadi sebelum selama dan setelah adanya suatu kegiatan/proyek. Beberapa faktor yang mempengaruhi kondisi tersebut adalah yang berkaitan dengan: (1). Curah hujan meliputi; lama waktu hujan, intensitas dan penyebarannya; dan (2). Karakteristik daerah aliran sungai (DAS) meliputi: bentuk dan ukuran DAS, topografi, tanah, geologi dan penggunaan lahan.

Melalui ujicoba terhadap perilaku infiltrasi air hujan yang jatuh pada berbagai jenis tanah yang berbeda. Dinas Konservasi Tanah Amerika Serikat (US SCS,1972) mengembangkan metode estimasi total volume limpasan dengan menggunakan data hujan yang tersedia, yaitu dikenal sebagai metode SCS. Adapun faktor-faktor yang mempengaruhi perilaku infiltrasi tanah tersebut untuk mendukung metode ini, a.l. : grup hidrologi tanah (bydrolic soil group), type penutupan lahan (land cover), kondisi hidrologis dan kelembaban tanah awal (antecedent moisture content/ $A M C$ ), dan cara bercocok tanam (cara pengelolaan lahan) (Sukresno.1999).

Dalam menentukan besarnya debit sungai berdasarkan hujan perlu ditinjau hubungan antara hujan dan aliran sungai. Besarnya aliran di dalam sungai ditentukan terutama oleh besarnya hujan, intensitas hujan, luas daerah hujan, lama waktu hujan, luas daerah aliran sungai dan ciri-ciri daerah aliran itu.

Dengan kemungkinan yang sama untuk timbul, intensitas hujan berkurang kalau intervalnya meningkat. Kalau hujan berlangsung lebih lama daripada lama waktu konsentrasi alirannya, intensitas rataratanya akan lebih kecil daripada kalau lama waktu hujan itu sama dengan lama waktu konsentrasi. Lama waktu konsentrasi ialah selang waktu antara permulaan hujan dan saat yang seluruh areal daerah alirannya ikut berperanan pada pengaliran sungai. Apabila 
lama hujan melebihi lama waktu konsentrasi, maka laju pengaliran didalam sungai akan kurang daripada kalau lama waktu hujannya sama dengan lama waktu konsentrasi. Sebaliknya, apabila lama waktu hujan lebih pendek daripada lama waktu konsentrasi, intensitas hujannya meningkat menjadi lebih tinggi, akan tetapi hanya sebagian dari areal daerah aliran ikut berperanan pada pengaliran sungai. Dengan demikian maka laju pengaliran maksimum terjadi kalau lama waktru hujan sama dengan lama waktu konsentrasi daerah alirannya.

Model Erosi MUSLE merupakan pengembangan dari persamaan Universal Soil Loss Equation (USLE) yang pertama kali diterbitkan dalam Agricultural Handbook No. 282 (1965) dan dipublikasikan lagi pada Agricultural Handbook No. 587 (1978).

Metode USLE sebagai suatu persamaan hanya dapat menduga besar erosi tanah tahunan yang berasal erosi permukaan yang terjadi pada bagian profil bentang lahan (landscape) dan tidak dapat menghitung deposisi yang terjadi. USLE juga tidak diperuntukkan untuk menghitung hasil sedimen yang berada pada hilirnya maupun bentuk erosi gully.

Selanjutnya persamaan pendugaan erosi dikembangkan oleh Williams (1975) yaitu menerapkan faktor erosivitas hujan (R) sebagai rainfall-runoff basis sebagai persamaan MUSLE (modified USLE).

\section{METODE PENELITIAN}

\section{Letak dan Luas}

Letak daerah penelitian berdasarkan unit DAS termasuk DAS Keduang, Solo Hulu, wilayah DAS Bengawan Solo, berdasarkan peta rupa bumi digital Indo- nesia, yang diterbitkan Bakosurtanal (Badan Koordinasi Survey dan Pemetaan Nasional), terletak pada: $7^{0} 42^{\prime} 27,16^{\prime \prime}-7^{0} 55^{\prime}$ 35,51" LS 11059 29,29 " - $111^{0} 13$ 30,00 "BT. Berdasarkan letak administrasi meliputi wilayah Kecamatan: Girimarto, Jatipurno, Sidoharjo, Jatisrono, Slogohimo dan Jatiroto yang semuanya termasuk Kabupaten Wonogiri.

Luas Sub DAS Keduang berdasarkan wilayah hidrologis adalah 35.993 ha (luas Sub DAS yang diukur sampai outlet pengukuran (Stasiun Pengamatan Arus Sungai/SPAS), sedangkan luas Sub DAS secara alamis adalah : 42.644 ha.

\section{Bahan dan Alat}

Bahan yang diperlukan untuk mendukung penelitian ini meliputi :

(1). Peta penggunaan lahan skala $1: 50.000$, peta geologi skala $1: 500.000$, peta tanah skala $1: 100.000$, dan peta rupa bumi Indonesia (Peta RBI) skala $1: 50.000$

(2). Citra landsat

Alat yang digunakan untuk penelitian meliputi :

1) Stasiun Pengamatan Arus Sungai (SPAS)

2) Stasiun Pengamatan Hujan (SPH)

3) Komputer

4) Sofware SPSS

\section{Pengumpulan Data}

Data yang dikumpulkan meliputi : (1). parameter hidrologi untuk mendukung estimasi volume limpasan (runoff) dengan metode $\boldsymbol{S} \boldsymbol{C S}$ yaitu : grup hidrologi tanah (bydrologic soil grup), tipe penutupan lahan ( land cover), kondisi hidrologi dan kelembaban tanah awal (antecedent moisture conten) $A M C$ ), dan cara bercocok tanam (cara pengelolaan lahan); (2). parameter hidrologi untuk mendukung estimasi debit maksi- 


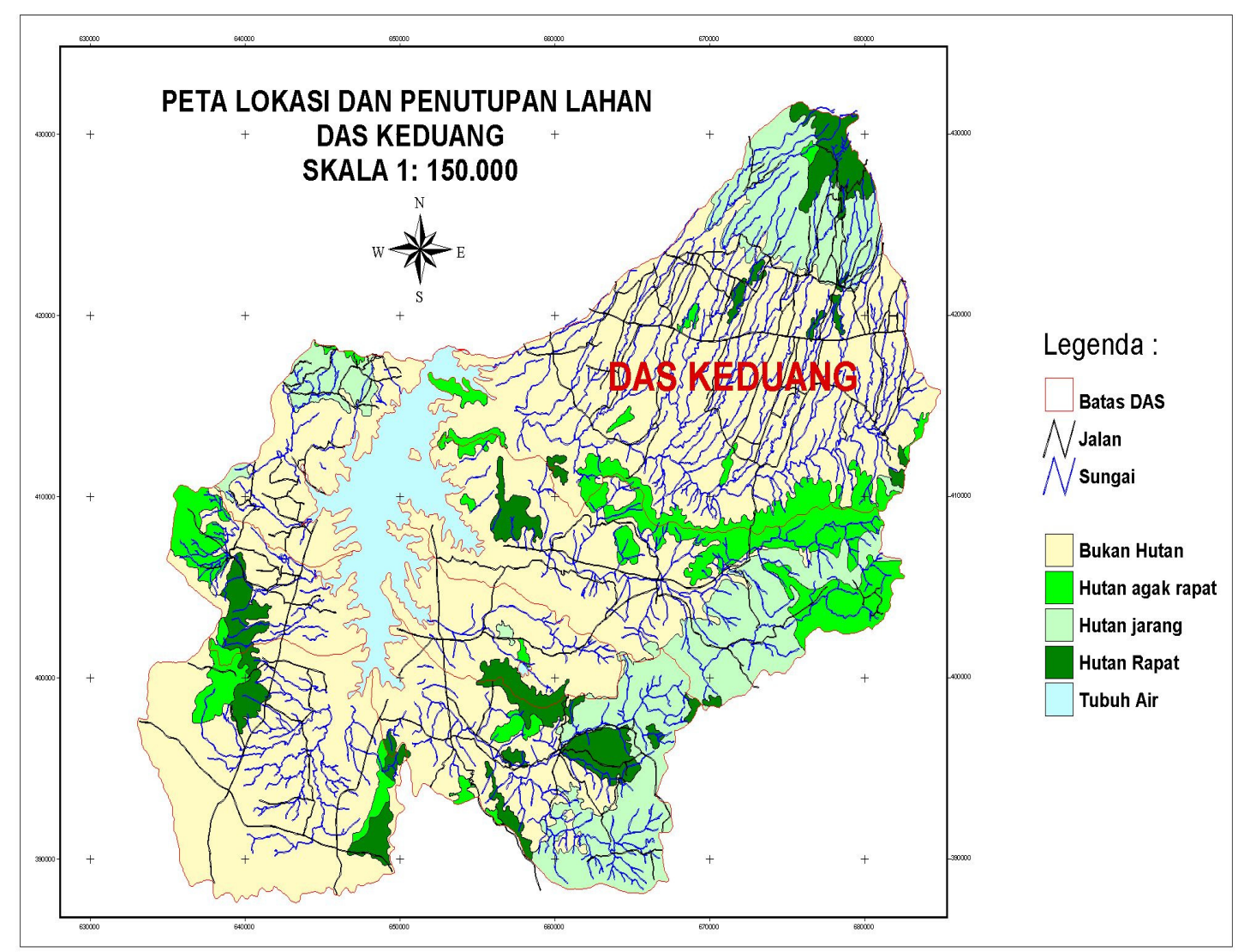

Gambar 1. Peta Lokasi dan Penutupan Lahan DAS Keduang

mum dengan metode rational yaitu : koefisien run off yang didasarkan pada faktorfaktor daerah pengalirannya seperti: jenis tanah, kemiringan lereng, keadaan hutan penutupnya dan besar kecilnya banjir, intensitas hujan selama time of concentration dan luas daerah pengaliran; dan (3). parameter hidrologi untuk estimasi erosi dan sedimentasi dengan metode MUSLE yaitu : erosivitas hujan sebagai runoff-rainfall basis $(\mathrm{Rm})$, erodibilitas tanah $(\mathrm{K})$, panjang lereng $(\mathrm{L})$, kemiringan lereng $(\mathrm{S})$, penutupan tanaman $(\mathrm{C})$, dan praktek konservasi $\operatorname{tanah}(\mathrm{P})$.

\section{Pengolahan dan Analisa Data}

a. Estimasi volume limpasan permukaan dengan metode $\boldsymbol{S} \boldsymbol{C S}$ yaitu :
Metode prakiraan total volume limpasan permukaan dari SCS ini, persamaannya adalah :

$$
\mathrm{Q}=\frac{(\mathrm{P}-0.2 \mathrm{~s})^{2}}{\mathrm{P}+0.8 \mathrm{~s}} \mathrm{P}^{3} 0.2 \mathrm{~s} \ldots \ldots \ldots
$$

dimana :

$\mathrm{Q}=$ limpasan permukaan $(\mathrm{mm})$

$\mathrm{P}=$ curah hujan $(\mathrm{mm})$

$\mathrm{s}=$ perbedaan antara curah hujan dan runoff $(\mathrm{mm})$

Besarnya perbedaan antara curah hujan dan limpasan permukaan ,s adalah berhubungan dengan angka kurva limpasan (CN) dimana persamaannya adalah : 


$$
\mathrm{S}=\left(\frac{1000}{\mathrm{CN}}-10\right)^{25,4} \ldots \ldots \ldots \ldots
$$

Angka CN (curve number) adalah bervariasi dari 0 sampai 100 yang dipengaruhi oleh kondisi grup hidrologi tanah AMC (antecedent moisture content), penggunaan lahan dan cara bercocok tanam. Kondisi $A M C$ rata-rata (II) angka $C N$ tersebut ditunjukkan pada Tabel 1.

Adapun grup hidrologi tanah (dibedakan atas A, B, C dan D dan untuk kondisi $A M C$ II ( rata-trata), dikategorikan menurut besarnya laju infiltrasi dan tekstur tanah, nilainya disajikan pada Tabel 2 . Kondisi $A M C$ (antecedent moisture content) I (kering) dan III (jenuh air) angka $C N$ langsung diperoleh dari Tabel 3, didasarkan pada angka $C N$ kondisi II.

b. Estimasi debit maksimum dengan metode rasional yaitu :

Rumus rasional adalah rumus yang tertua dan yang terkenal diantara rumus-rumus empiris. Untuk pertama-tama digunakan di Irlandia oleh Mulvaney pada tahun 1847.

Pemikiran secara rasional ini dapat dinyatakan secara aljabar dengan rumus rasional berikut :

Tabel 1. Angka CN (curve number) untuk kondisi $A M C$ (antecedent moisture content) II (kondisi rata-rata)

\begin{tabular}{|c|c|c|c|c|c|c|c|}
\hline \multirow{2}{*}{$\begin{array}{c}\text { Penggunaan } \\
\text { lahan }\end{array}$} & \multirow{2}{*}{ Tipe Penutupan } & \multirow{2}{*}{$\begin{array}{c}\text { Cara } \\
\text { Pengelolaan }\end{array}$} & \multirow{2}{*}{$\begin{array}{l}\text { Kondisi } \\
\text { Hidrologi }\end{array}$} & \multicolumn{4}{|c|}{ Grup Hidrologi Tanah } \\
\hline & & & & $\mathbf{A}$ & B & C & D \\
\hline (1) & (2) & (3) & (4) & (5) & (6) & (7) & $(8)$ \\
\hline \multirow{27}{*}{ Pertanian } & Bera & Tanah terbuka & & 77 & 86 & 91 & 94 \\
\hline & Tanaman berjajar & Larikan lurus & Buruk & 72 & 81 & 88 & 91 \\
\hline & & Larikan lurus & Baik & 67 & 78 & 85 & 89 \\
\hline & & Kontur & Buruk & 70 & 79 & 84 & 88 \\
\hline & & Kontur & Baik & 65 & 75 & 82 & 86 \\
\hline & & Kontur \& teras & Buruk & 66 & 74 & 80 & 82 \\
\hline & & Kontur \& teras & Baik & 62 & 71 & 78 & 81 \\
\hline & Padi, gandum & Larikan lurus & Buruk & 65 & 76 & 84 & 88 \\
\hline & & Larikan lurus & Baik & 63 & 75 & 83 & 87 \\
\hline & & Kontur & Buruk & 63 & 74 & 82 & 85 \\
\hline & & Kontur & Baik & 61 & 73 & 81 & 84 \\
\hline & & Kontur \& teras & Buruk & 61 & 72 & 79 & 82 \\
\hline & & Kontur \& teras & Baik & 59 & 70 & 78 & 81 \\
\hline & Tanaman legum & Larikan lurus & Buruk & 66 & 77 & 85 & 89 \\
\hline & & Larikan lurus & Baik & 58 & 72 & 81 & 84 \\
\hline & & Kontur & Buruk & 64 & 75 & 83 & 85 \\
\hline & & Kontur & Baik & 55 & 69 & 78 & 83 \\
\hline & & Kontur \& teras & Buruk & 63 & 73 & 80 & 83 \\
\hline & & Kontur \& teras & Baik & 51 & 67 & 76 & 80 \\
\hline & Lapangan rumput & & Buruk & 68 & 79 & 86 & 89 \\
\hline & & & Sedang & 49 & 69 & 79 & 84 \\
\hline & & & Baik & 39 & 61 & 74 & 80 \\
\hline & Padang rumput & & & 30 & 58 & 71 & 78 \\
\hline & Tegakan hutan & & Buruk & 45 & 66 & 77 & 83 \\
\hline & & & Sedang & 36 & 60 & 73 & 79 \\
\hline & Kajian Model Estimasi Volt & Ime Limpasan Pe & Bboldidxan .... ( & $\lg 61$ & $r 55 M u$ & $t i$ bno & 77 \\
\hline & Pekarangan rumah & & - & 59 & 74 & 82 & 86 \\
\hline \multirow[t]{3}{*}{$\begin{array}{l}\text { Padang rumput } \\
\text { (iklim kering) }\end{array}$} & $\begin{array}{l}\text { Tanaman perdu (rumput- } \\
\text { an \& tanaman bawah) }\end{array}$ & & $\begin{array}{l}\text { Buruk } \\
(<30 \%)\end{array}$ & & 80 & 87 & 93 \\
\hline & & & Sedang & & 71 & 81 & 89 \\
\hline & & & Baik $(70 \%)$ & & 62 & 74 & 79 \\
\hline
\end{tabular}




\begin{tabular}{|c|c|c|c|c|c|c|c|}
\hline \multirow{2}{*}{$\begin{array}{l}\text { Penggunaan } \\
\text { lahan }\end{array}$} & \multirow{2}{*}{ Tipe Penutupan } & \multirow{2}{*}{$\begin{array}{c}\text { Cara } \\
\text { Pengelolaan }\end{array}$} & \multirow{2}{*}{$\begin{array}{l}\text { Kondisi } \\
\text { Hidrologi }\end{array}$} & \multicolumn{4}{|c|}{ Grup Hidrologi Tanah } \\
\hline & & & & A & B & $\mathrm{C}$ & D \\
\hline \multirow[t]{2}{*}{ (1) } & (2) & (3) & (4) & (5) & (6) & (7) & $(8)$ \\
\hline & Pekarangan rumah & & - & 59 & 74 & 82 & 86 \\
\hline \multirow[t]{9}{*}{$\begin{array}{l}\text { Padang rumput } \\
\text { (iklim kering) }\end{array}$} & $\begin{array}{l}\text { Tanaman perdu (rumput- } \\
\text { an \& tanaman bawah) }\end{array}$ & & $\begin{array}{l}\text { Buruk } \\
(<30 \%)\end{array}$ & & 80 & 87 & 93 \\
\hline & & & Sedang & & 71 & 81 & 89 \\
\hline & & & Baik $(70 \%)$ & & 62 & 74 & 79 \\
\hline & Perdu daerah pegunungan & & Buruk & & 66 & 74 & 79 \\
\hline & & & Sedang & & 48 & 57 & 63 \\
\hline & & & Baik & & 30 & 41 & 48 \\
\hline & Perdu padang pasir & & Buruk & 63 & 77 & 85 & 88 \\
\hline & & & Sedang & 55 & 72 & 81 & 86 \\
\hline & & & Baik & 49 & 68 & 79 & 84 \\
\hline \multirow[t]{19}{*}{ Perkotaan } & Telah berkembang: & & & & & & \\
\hline & -Taman kota berumput & & Buruk $(2 \%)$ & 68 & 79 & 86 & 89 \\
\hline & & & Sedang & 49 & 69 & 79 & 84 \\
\hline & & & Baik $(75 \%)$ & 39 & 61 & 74 & 80 \\
\hline & $\begin{array}{l}\text { - Kawasan beraspal dan } \\
\text { berbeton }\end{array}$ & & & 98 & 98 & 98 & 98 \\
\hline & - Jalan tanah & & & 72 & 82 & 87 & 89 \\
\hline & - Jalan aspal/beton & & & 98 & 98 & 98 & 98 \\
\hline & - Jalan berbatu & & & 76 & 85 & 89 & 91 \\
\hline & $\begin{array}{l}\text { - Jalan aspal/beton } \\
\text { Bersaluran Terbuka }\end{array}$ & & & 83 & 89 & 92 & 93 \\
\hline & Wilayah: & & & & & & \\
\hline & $\begin{array}{l}\text { - Pertokoan }(85 \% \text { kedap } \\
\text { air (ka) }\end{array}$ & & & 89 & 92 & 94 & 95 \\
\hline & $\begin{array}{ll}\text { - } & \text { Industri } \\
& (72 \% \mathrm{ka})\end{array}$ & & & 81 & 88 & 91 & 93 \\
\hline & $\begin{array}{l}\text { - Perumahan } \\
\text { (halaman (h) } 500 \\
\text { m2, } 65 \% \mathrm{ka})\end{array}$ & & & 77 & 85 & 90 & 92 \\
\hline & $\begin{array}{l}\text { - Perumahan } \\
(\mathrm{h}+1000 \mathrm{~m} 2,38 \% \mathrm{ka})\end{array}$ & & & 61 & 75 & 83 & 87 \\
\hline & $\begin{array}{l}\text { - Perumahan } \\
(\mathrm{h}+1350 \mathrm{~m} 2,30 \% \mathrm{ka})\end{array}$ & & & 57 & 72 & 81 & 86 \\
\hline & $\begin{array}{l}\text { - Perumahan } \\
(\mathrm{h} \pm 2000 \mathrm{~m} 2,25 \% \mathrm{ka})\end{array}$ & & & 54 & 70 & 80 & 85 \\
\hline & $\begin{array}{l}\text { - Perumahan } \\
(\mathrm{h}+4000 \mathrm{~m} 2,20 \% \mathrm{ka})\end{array}$ & & & 51 & 68 & 79 & 84 \\
\hline & $\begin{array}{l}\text { - Perumahan } \\
(\mathrm{h}+8000 \mathrm{~m} 2,12 \% \mathrm{ka})\end{array}$ & & & 46 & 65 & 77 & 82 \\
\hline & $\begin{array}{l}\text { - Pengembangan } \\
\text { Kota ( tanpa vegetasi) }\end{array}$ & & & 77 & 86 & 91 & 94 \\
\hline
\end{tabular}

Sumber : McCuen (1989) dan US SCS (1972) 
Tabel 2. Grup Hidrologi Tanah (bydrolic soil group)

\begin{tabular}{|c|c|l|}
\hline Grup Tanah & Laju infiltrasi (mm/jam) & \multicolumn{1}{c|}{ Tekstur } \\
\hline A & $8-12$ & Pasir, pasir berlempung dan lempung berpasir \\
\hline B & $4-8$ & Lempung berdebu, lempung \\
\hline C & $1-4$ & Lempung pasir berliat \\
\hline D & $0-1$ & $\begin{array}{l}\text { Lempung berliat, lempung debu berliat, liat } \\
\text { berpasir, liat berdebu, liat }\end{array}$ \\
\hline
\end{tabular}

Sumber : McCuen (1989) dan US SCS (1972)

Tabel 3. Angka $C N$ untuk kondisi $A M C$ I (kering) dan III (jenuh air dengan hujan terjadi pada 5 hari terakhir).

\begin{tabular}{|c|c|c|}
\hline \multicolumn{3}{|c|}{$\begin{array}{l}\text { Angka } C N(\text { II) untuk kondisi } A M C \text { I (kering) dan } \\
A M C \text { III (jenuh air dengan hujan terjadi pada } 5 \text { hari terakhir) }\end{array}$} \\
\hline Angka $C N($ II $)$ & $\begin{array}{c}\text { Kondisi } A M C \text { I } \\
\text { (kering) }\end{array}$ & $\begin{array}{l}\text { Kondisi } A M C \text { III (jenuh air dengan } \\
\text { hujan terjadi pada } 5 \text { hari terakhir) }\end{array}$ \\
\hline 100 & 100 & 100 \\
\hline 95 & 87 & 99 \\
\hline 90 & 78 & 98 \\
\hline 85 & 70 & 97 \\
\hline 80 & 63 & 94 \\
\hline 75 & 57 & 91 \\
\hline 65 & 45 & 83 \\
\hline 60 & 40 & 79 \\
\hline 55 & 35 & 75 \\
\hline 50 & 31 & 70 \\
\hline 45 & 27 & 65 \\
\hline 40 & 23 & 60 \\
\hline 35 & 19 & 55 \\
\hline 30 & 15 & 50 \\
\hline 25 & 12 & 45 \\
\hline 20 & 9 & 39 \\
\hline 15 & 7 & 33 \\
\hline 10 & 4 & 26 \\
\hline 5 & 2 & 17 \\
\hline 0 & 0 & 0 \\
\hline
\end{tabular}

Sumber : McCuen (1989) dan US SCS (1972) 
$\mathrm{Q}=$ C.I.A. $\mathrm{cfs}$ (cubic feet per second atau second feet)

$\mathrm{A}=$ luas daerah aliran sungai dalam acres

$\mathrm{I}=$ intensitas hujan maksimum selama waktu yang sama dengan lama waktu konsentrasi, dinyatakan dalam inchi tiap jam

$\mathrm{C}=$ angka pengaliran (koefisien runoff), tak berdimensi.

Apabila digunakan satuan metrik, maka rumus rasional menjadi :

$$
\mathrm{Q}=0,278 \text { C.I.A. } \mathrm{m} 3 / \mathrm{dt} \text {. }
$$

I : dalam mm tiap jam

A : dalam $\mathrm{km} 2$.

a. Koefisien run off yang didasarkan pada faktor-faktor daerah pengalirannya seperti : jenis tanah, kemiringan, keadaan hutan penutupnya dan besar kecilnya banjir, intensitas hujan selama time of concentration dan luas daerah pengaliran.

Besarnya koefisien runoff ( C ) didasarkan pada keadaan daerah pengaliran seperti terlihat pada Tabel 4.

b. Intensitas hujan (I) didapat dari persamaan :

$$
\mathrm{I}=\frac{\mathrm{R}}{24} \cdot\left(\frac{24}{T_{c}}\right)^{2 / 3}
$$

I = intensitas hujan hujan selama time of concentration ( $\mathrm{mm} / \mathrm{jam})$

$\mathrm{R}=$ hujan sehari $(\mathrm{mm})$

$T_{c}=$ time of concentration (jam)

$$
\left(0,869 \times \mathrm{L}^{3}\right)^{0,385}
$$

\section{$\mathrm{H}$}

$T_{c}=$ time of concentration ( $\left.\mathrm{jam}\right)$

$\mathrm{L}=$ panjang sungai utama $(\mathrm{km})$

$\mathrm{H}=$ beda tinggi antara titik tertinggi dengan titik terendah pada catchment area $(\mathrm{m})$

c. Luas DAS (A) dalam km2

3) Estimasi perhitungan erosi tanah dengan metode MUSLE

Metode USLE sebagai suatu persamaan hanya dapat menduga besar erosi tanah tahunan yang berasal erosi permukaan yang terjadi pada bagian profil bentang lahan (landscape) dan tidak dapat

Tabel 4. Perhitungan Koefisien Runoff

\begin{tabular}{|c|l|c|}
\hline No. & \multicolumn{1}{|c|}{ Keadaan daerah pengaliran } & Koefisien runoff \\
\hline 1. & Bergunung dan curam & $0,75-0,90$ \\
\hline 2. & Pegunungan tersier & $0,70-0,80$ \\
\hline 3. & $\begin{array}{l}\text { Sungai dengan tanah dan hutan dibagian atas dan } \\
\text { bawahnya }\end{array}$ & $0,50-0,75$ \\
\hline 4. & Tanah dasar yang diairi & $0,45-0,60$ \\
\hline 5. & Sawah waktu diairi & $0,70-0,80$ \\
\hline 6. & Sungai bergunung & $0,75-0,85$ \\
\hline 7. & Sungai dataran & $0,45-0,75$ \\
\hline
\end{tabular}

Sumber : Sosrodarsono, 1993 
menghitung deposisi yang terjadi. USLE juga tidak diperuntukkan untuk menghitung hasil sedimen yang berada pada hilirnya maupun bentuk erosi gully.

Selanjutnya persamaan pendugaan erosi juga dikembangkan oleh Williams (1975) yaitu menerapkan faktor erosivitas hujan (R) sebagai rainfall-runoff basis sebagai persamaan MUSLE (modified USLE), sehingga persamaannya menjadi :

$$
A=\mathrm{Rm} \times \mathrm{K} \times \mathrm{L} \times \mathrm{S} \times \mathrm{C} \times \mathrm{P} .
$$

dimana :

$\mathrm{Rm}=11,8$ (Q qp) ${ }^{0,56}$

$\mathrm{Q}=$ total volume runoff $(\mathrm{m} 3)$

$\mathrm{qp}=$ adalah puncak banjir $(\mathrm{m} 3 / \mathrm{dt})$

a). $\mathrm{Rm}$ : erosivitas hujan merupakan faktor $\mathrm{R}$ pada MUSLE, yang dicari dengan menggunakan nilai total volume runoff dan debit puncak, dimana Rm (Williams dan Berndt,1977) :

$$
\mathrm{Rm}=11,8(\mathrm{Q} q \mathrm{p})^{0,56}
$$

$\mathrm{Q}=$ total volume runoff $(\mathrm{m} 3)$

$\mathrm{qp}=$ adalah puncak banjir $(\mathrm{m} 3 / \mathrm{dt})$ yang dihitung dengan melalui pengamatan tinggi muka air otomatis (AWLR), pada tinggi muka air yang tertinggi, kemudian disubstitusikan kedalam persamaan hubungan tinggi muka air dengan debit aliran (discharge rating curve)

b). K: erodibilitas tanah yang dihitung dengan nomograph USLE, dari Wischmeier dan Smith, dimana parameter-parameternya adalah fraksi pasir sangat halus + debu (\%), fraksi pasir $(\%)$, bahan organik (\%) dengan 5 (lima) kelas, struktur tanah 4 (empat) kelas dan permeabilitas tanah 6 (enam kelas). Nilai K ini juga dapat dihitung dengan persamaan:

$100 \mathrm{~K}=2,1 \mathrm{M} 1,14\left(10^{-4}\right)$

$(12-\mathrm{aU})+3,25(\mathrm{~b}-2)+2,5(\mathrm{c}-3) \ldots(8)$ dimana untuk memperoleh nilai satuan metrik, maka nilai $\mathrm{K}$ adalah :

$\mathrm{K}=1,292 \times$ nilai $\mathrm{K}$

c). LS : faktor panjang dan kemiringan lereng yang dihitung dengan persamaan

$$
\begin{aligned}
& \mathrm{L}=(1 / 22,1)^{1 / 2} \ldots \ldots \ldots \ldots \ldots \ldots \\
& \mathrm{S}=65,41 \sin 2 \mathrm{a}+4,56 \mathrm{a} \\
& \quad+0,065
\end{aligned}
$$

d). C dan P : berupa faktor penutupan tanah oleh tanaman $(\mathrm{C})$ dan praktek konservasi tanah $(\mathrm{P})$ yang dihitung berdasarkan nilai-nilai yang telah diadopsi untuk kondisi Indonesia.

\section{HASIL DAN PEMBAHASAN}

\section{Estimasi Volume Limpasan Permukaan dengan Model SCS}

Perhitungan masing-masing faktor untuk Model $\boldsymbol{S} \boldsymbol{C S}$ adalah sebagai berikut :

1. Faktor angka Curve Number (CN) disajikan pada Tabel 5.

2. Perbedaan antara curah hujan dan limpasan permukaan (s)

Besarnya perbedaan antara curah hujan dan limpasan permukaan (s) adalah berhubungan dengan angka kurva limpasan permukaan $(\mathrm{CN})$ dimana persamaannya adalah :

$$
S=\left(\frac{1000}{C N}-10\right) 25,4 \text { atau }
$$


Tabel 5. Perhitungan angka Curve Number (CN) DAS Keduang

\begin{tabular}{|c|c|c|c|c|c|}
\hline No. & Luas (ha) & $\begin{array}{l}\text { Kelompok } \\
\text { tanah }\end{array}$ & $\begin{array}{l}\text { Tipe landuse, Perlakuan, } \\
\text { Kondisi tanah }\end{array}$ & Angka $C N$ & $\begin{array}{r}\mathbf{C N} \\
\text { Tertimbang }\end{array}$ \\
\hline 1 & 2 & 3 & 4 & 5 & $6=2 \times 5$ \\
\hline 1 & $7.971,191$ & D & Pekarangan rumah & 86 & $685.522,43$ \\
\hline 2 & 255,671 & $\mathrm{D}$ & Lapangan rumput,baik & 80 & $20.453,664$ \\
\hline 3 & $2.528,760$ & $\mathrm{D}$ & Tegakan hutan, baik & 77 & $194.714,52$ \\
\hline 4 & $1.288,148$ & A & Tegakan hutan, sedang & 36 & $46.373,328$ \\
\hline 5 & $3.446,809$ & A & Tegakan hutan, buruk & 45 & $155.106,39$ \\
\hline 6 & $12.948,285$ & $\mathrm{D}$ & Padi, larikan lurus, baik & 87 & $11.265,008$ \\
\hline \multirow[t]{2}{*}{7} & $8.341,739$ & $\mathrm{D}$ & Legum, kontur dan teras baik & 80 & $667.339,12$ \\
\hline & $36.780,603$ & & & & 2.896 .010 .2 \\
\hline \multicolumn{6}{|c|}{ Angka $C N$ tertimbang $=2.896 .010,2445 / 36.780,603=\mathbf{7 8 , 7 4}$} \\
\hline
\end{tabular}

Sumber : hasil perhitungan

$S=\left(\frac{25400}{C N}-254\right)$

sehingga $(\mathrm{s})=(25400 / C N)-254$

$(\mathrm{s})=(25.400 / 78,74)-254$ $=68,58$

3. Volume Limpasan Permukaan Volume limpasan permukaan (runoff) dengan persamaan :

$$
\mathrm{Q}=\frac{(\mathrm{P}-0.2 \mathrm{~s})^{2}}{\mathrm{P}+0.8 \mathrm{~s}}
$$

dimana :

$\mathrm{Q}=$ limpasan permukaan $(\mathrm{mm})$

$\mathrm{P}=\operatorname{curah}$ hujan sesaat $(\mathrm{mm})=108 \mathrm{~mm}$, (hujan maksimum terjadi pada tanggal 20-Desember-2005)

$\mathrm{s}=$ perbedaan antara curah hujan dan runoff $(\mathrm{mm})$

$$
\begin{aligned}
Q= & \{108-(0,2 \times 68,58)\}^{2} / \\
& (108+(0,8 \times 68,58)\} \\
= & 8889.4726 / 162.864=\mathbf{5 4 , 5 8} \mathbf{~ m m}
\end{aligned}
$$

4. Total volume limpasan permukaan (runoff) pada kejadian hujan maksimum sebesar 108 mm (20-Desember-2005)

Total volume limpasan permukaan (Q) untuk DAS Keduang pada tanggal

20 Desember $2005=$

$54,58 \times 1 / 1000 \mathrm{~m} \times 36.780,603 \times 10.000 \mathrm{~m}$ $=20.056 .462,82 \mathrm{~m}$

Perhitungan hasil total volume limpasan permukaan terprediksi (Q-SCS) di DAS Keduang pada kejadian hujan maksimum sebesar $108 \mathrm{~mm}$ pada tanggal 20 Desember 2005 nilainya sebesar 20.056 . 462,82 m3 dibandingkan dengan nilai aktual yang diperoleh dari hasil pengamatan hidrologi (SPAS) pada tanggal 20 Desember 2005 nilainya sebesar 15.482 . $534,40 \mathrm{~m} 3$, sehingga terdapat selisih + $4.573 .928,40 \mathrm{~m} 3(29,54 \%)$. Hal ini menunjukkan bahwa metode SCS yang diterapkan pada DAS Keduang terjadi over estimate dalam memprediksi total volume limpasan permukaan. 
Model Estimasi Debit Puncak Aliran Dengan Model Rasional

Dalam mengestimasi debit maksimum ( $q p$ ) dengan metode rasional digunakan persamaan berikut :

$$
q p=0,278 \text { C.I.A. } \mathrm{m} 3 / \mathrm{dt} \text {. }
$$

dimana

A = luas daerah aliran sungai dalam $\mathrm{km} 2$

$\mathrm{I}=$ intensitas hujan maksimum selama waktu yang sama dengan lama waktu konsentrasi, dinyatakan dalam mm tiap jam

$\mathrm{C}=$ Koefisien run off yang didasarkan pada faktor-faktor daerah pengalirannya seperti : jenis tanah, kemiringan, keadaan hutan penutupnya dan besar kecilnya banjir, intensitas hujan selama time of concentration dan luas daerah pengaliran.

1. Besarnya koefisien runoff(C) didasarkan pada keadaan daerah pengaliran seperti terlihat pada Tabel 6.

2. Intensitas hujan (I) didapat dari persamaan :

$$
\mathrm{I}=\frac{\mathrm{R}}{25} \ldots\left(\frac{24}{\mathrm{Tc}}\right)^{2 / 3}
$$

$$
\begin{aligned}
& \text { of concentration }(\mathrm{mm} / \mathrm{jam}) \\
& \mathrm{R}=\text { hujan sehari }(\mathrm{mm}) \\
& \mathrm{T}_{c}=\text { time of concentration }(\mathrm{jam})
\end{aligned}
$$$$
\mathrm{I}=\text { intensitas hujan hujan selama time }
$$

$$
T c=\underline{\left(0,869 \times \mathrm{L}^{3}\right)^{0,385}}
$$

$\mathrm{H}$

$$
\begin{aligned}
T_{c}= & \text { time of concentration }(\mathrm{jam}) \\
\mathrm{L}= & \text { panjang sungai utama }(\mathrm{km})=37,82 \\
& \mathrm{~km} . \\
\mathrm{H}= & \text { beda tinggi antara titik tertinggi } \\
& \text { dengan titik terendah pada catchment } \\
& \text { area }(\mathrm{m}) \\
& 925-150=1725 \mathrm{~m} .
\end{aligned}
$$

$$
\mathrm{Tc}=\left(\frac{0,867 \mathrm{X} \mathrm{L}^{3}}{\mathrm{H}}\right)^{0,385}
$$

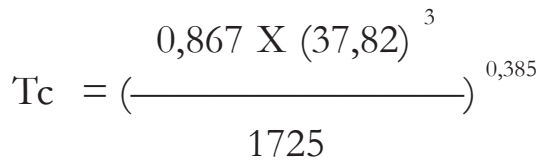

$$
\begin{aligned}
& \mathrm{Tc}=\left(\frac{46.901,1694}{1725}\right)^{0,385} \\
& \mathrm{Tc}=\mathbf{3 , 5 7} \mathrm{jam}
\end{aligned}
$$

Tabel 6. Perhitungan Koefisien Runoff di sub DAS Keduang

\begin{tabular}{|c|l|c|c|c|c|}
\hline \multirow{2}{*}{ No. } & \multirow{2}{*}{ Kondisi Sungai } & \multicolumn{2}{|c|}{ Luas } & \multirow{2}{*}{ Nilai C } & \multirow{2}{*}{ Nilai C Tertimbang } \\
\cline { 3 - 4 } & (ha) & $(\%)$ & 0,60 & 0,087 \\
\hline 1. & Sungai dataran & 5.331 & 14,49 & 0,586 \\
\hline 2. & Sungai bergunung & 26.935 & 73.23 & 0,80 & 0,101 \\
\hline 3. & $\begin{array}{l}\text { Sungai bergunung dan } \\
\text { curam }\end{array}$ & 4.515 & 12,28 & 0,825 & $\mathbf{0 , 7 7 4}$ \\
\hline \multicolumn{5}{|c|}{ Koefisien Runoff ( C ) rata-rata tertimbang } & \\
\hline
\end{tabular}




$$
\begin{aligned}
& I=\frac{\mathrm{R}}{24} \cdot\left(\frac{24}{T_{c}}\right)^{2 / 3} \\
& I=\frac{108}{24} \cdot\left(\frac{24}{3.57}\right)^{2 / 3} \\
& I=4,50 \cdot 3,585=16,13 \mathrm{~mm} / \mathbf{j a m}
\end{aligned}
$$

3. Luas DAS (A) dalam $\mathrm{km} 2$

Luas DAS (A) Keduang $=367,81 \mathrm{~km} 2$

4. Estimasi debit aliran puncak ( $q p)$ DAS Keduang berdasarkan model rasional $q p=0,278$ C.I.A. $\mathrm{m} 3 / \mathrm{dt}$. $q p=0,278 \times 0,774 \times 16,13 \times 367,81 \mathrm{~m} 3 / \mathrm{dt}$. $q p=1.276,57 \mathrm{~m} 3 / \mathrm{dt}$.

Perhitungan hasil debit puncak aliran terprediksi (qp-rasional) di DAS Keduang pada kejadian hujan maksimum $=108 \mathrm{~mm}$ dan tinggi muka air maksimum $=3,30 \mathrm{~m}$ pada tanggal 20 Desember 2005 nilainya sebesar $1.276,5671 \mathrm{~m} 3 / \mathrm{dt}$ dibandingkan dengan nilai aktualnya yang diperoleh dari hasil pengamatan hidrologi (SPAS) yang terjadi pada tanggal 20 Desember 2005 dengan tinggi muka air maksimum $=3,30$ $\mathrm{m}$, nilainya sebesar $638,819 \mathrm{~m} 3 / \mathrm{dt}$, sehingga terjadi penyimpangan serbesar + $637.7481 \mathrm{~m} 3 / \mathrm{dt}(49,96 \%)$. Hal ini menunjukkan bahwa untuk metode rasional yang diterapkan di DAS Keduang terjadi over estimate dalam memprediksi debit puncak aliran.

\section{Model Estimasi Erosi Dengan Model MUSLE}

Parameter yang dihitung dalam memprediksi erosi tanah dengan metode MUSLE adalah sebagai berikut

1). Rm : erosivitas hujan merupakan faktor

$\mathrm{R}$ pada MUSLE, yang dicari dengan menggunakan nilai total volume runoff dan debit puncak aliran, dimana $\mathrm{Rm}$ (Williams dan Berndt,1977) :

$$
\begin{aligned}
\mathrm{Rm}=11,8(\mathrm{Q} q \mathrm{p}) & 0,56 \\
\mathrm{Q}= & \text { total volume runoff (m3) yang } \\
& \text { dihitung dengan metode bilangan } \\
& \text { kurva (SCS) } \\
q p= & \text { adalah puncak banjir (m3/dt) yang } \\
& \text { dihitung dengan rumus rasional. } \\
\mathrm{Rm}= & 11,8(\mathrm{Q} \text { qp) } \\
\mathrm{Rm}= & 11,8(20.056 .462 \times 1.276,57)^{0,56} \\
\mathrm{Rm}= & \mathbf{5 4 8 1 , 1 2 4 1}
\end{aligned}
$$

2). $\mathrm{K}$ : erodibilitas tanah yang dihitung dengan nomograph USLE, dari Wischmeier dan Smith, dimana parameter-parameternya adalah fraksi pasir sangat halus + debu (\%), fraksi pasir $(\%)$, bahan organik (\%) dengan 5 (lima) kelas, struktur tanah 4 (empat) kelas dan permeabilitas tanah 6 (enam kelas). Nilai $\mathrm{K}$ ini juga dapat dihitung dengan persamaan :

$100 \mathrm{~K}=2,1 \mathrm{M} 1,14\left(10^{-4}\right)(12-\mathrm{a})+$ $3,25(\mathrm{bU}-2)+2,5(\mathrm{c}-3)$

dimana untuk memperoleh nilai satuan metrik, maka nilai $\mathrm{K}$ adalah :

$\mathrm{K}=1,292 \times$ nilai $\mathrm{K}$

Nilai K ( erodibilitas tanah ) DAS Keduang disajikan dalam Tabel 11.

3). LS : faktor panjang dan kemiringan lereng yang dihitung dengan persamaan

$$
\begin{aligned}
& \mathrm{L}=(1 / 22,1)^{1 / 2} \\
& \mathrm{~S}=65,41 \sin 2 \mathrm{a}+4,56 \mathrm{a}+0,065
\end{aligned}
$$


Tabel 7. Nilai K (erodibilitas tanah) DAS Keduang

\begin{tabular}{|c|c|c|c|c|c|c|}
\hline \multirow{2}{*}{ No. } & \multirow{2}{*}{ Jenis tanah } & \multirow{2}{*}{ Batuan induk } & \multirow{2}{*}{$\mathbf{K}$} & \multicolumn{2}{|c|}{ Luas } & \multirow{2}{*}{ K tertimbang } \\
\hline & & & & (ha) & $(\%)$ & \\
\hline$(1)$ & (2) & (3) & (4) & (5) & (6) & $(7)=(4) \times(6)$ \\
\hline 1. & Lithosol & Breksi & 0,015 & 3.593 & 9,77 & 0,0015 \\
\hline 2. & Lithosol & Vulkanik/lava & 0,03 & 5.392 & 14,66 & 0,0044 \\
\hline 3. & Gromusol & Napel & 0,24 & 353 & 0,96 & 0,0023 \\
\hline 4. & Mediteran & Tuff Vulkan & 0,18 & $15 . .577$ & 42,35 & 0,0762 \\
\hline 5. & Latosol & Tuff vulkan & 0,16 & 11.866 & 32,26 & 0,0516 \\
\hline \multicolumn{6}{|c|}{ Nilai K (erodibilitas tanah) tertimbang } & 0,1360 \\
\hline
\end{tabular}

Faktor panjang dan kemiringan lereng (faktor LS ) DAS Keduang dihitung dengan bantuan peta topografi dengan persamaan McCool dkk. (1987). Hasil nilai panjang dan kemiringan lereng (faktor LS ) sub DAS Keduang adalah $=17,3$ (BTP DAS, 2001)

4). C dan P : berupa faktor penutupan tanah oleh tanaman $(\mathrm{C})$ dan praktek konservasi tanah $(\mathrm{P})$ yang dihitung berdasarkan nilai-nilai yang telah diadopsi untuk kondisi Indonesia.

Nilai C dan P di DAS Keduang hasilnya disajikan pada Tabel 8.
5). Hasil prediksi tingkat erosi tanah (A) dari MUSLE dihitung berdasarkan persamaan umum kehilangan tanah (USLE) sebagai berikut :

$$
\begin{aligned}
\mathrm{A}= & 70.687 .029,01 \times 0,1360 \times 17,30 \\
& \mathrm{x} 0,035 \\
= & \mathbf{5 . 8 2 0 . 9 3 5 , 4 6 5} \text { ton }=\mathbf{1 5 8 , 2 6 1 0} \\
& \text { ton } / \mathbf{h a} / \mathbf{t h}
\end{aligned}
$$

Perhitungan hasil erosi tanah (A) dari MUSLE terprediksi (A-MUSLE) di DAS Keduang tahun 2005 sebesar 158,2610 ton/ha/th dibandingkan dengan nilai

\begin{tabular}{|c|c|c|c|c|c|c|}
\hline \multirow{2}{*}{ No. } & \multirow{2}{*}{ Landuse } & \multirow{2}{*}{ Nilai C } & \multirow{2}{*}{ Nilai $P$} & \multicolumn{2}{|c|}{ Luas } & \multirow{2}{*}{ Nilai CP } \\
\hline & & & & (ha) & $(\%)$ & \\
\hline (1) & (2) & (3) & (4) & (5) & (6) & $(7)=(3) \times(4) \times(6)$ \\
\hline 1. & Hutan & 0,01 & 1,00 & 4.083 & 11,1 & 0,001 \\
\hline 2. & Hutan dan semak & 0,15 & 1.00 & 2.244 & 6,1 & 0,009 \\
\hline 3. & Sawah & 0,10 & 0,04 & $15 . .521$ & 42,2 & 0,001 \\
\hline 4. & Kampung & 0,40 & 0,15 & 5.076 & 13,8 & 0,008 \\
\hline 5. & Tegal & 0,50 & 0,15 & 7.209 & 19,6 & 0,015 \\
\hline 6 & Tegal/hutan rakyat & 0,10 & 0,15 & 2.648 & 7,2 & 0,001 \\
\hline \multicolumn{6}{|c|}{ Nilai $C P$ rata-rata tertimbang $=$} & 0,035 \\
\hline
\end{tabular}
aktualnya yang diperoleh dari hasil

Tabel 8. Nilai C dan P rata-rata tertimbang DAS Keduang 
pengamatan hidrologi (SPAS) tahun 2005 nilainya sebesar 106,5931 ton/ha/th, sehingga terjadi penyimpangan sebesar + 51,6679 ton/ha/th $(48,47 \%)$. Hal ini menunjukkan bahwa metode perhitungan erosi tanah dari MUSLE (A-MUSLE) yang diterapkan pada DAS Keduang terjadi over estimate dalam memprediksi erosi tanah.

\section{KESIMPULAN}

1. Metode Soil Conservation Service (SCS) terjadi over estimate sebesar 29,54\% dalam memprediksi volume aliran permukaan pada DAS Keduang, dibandingkan dengan nilai aktualnya yang diperoleh dari hasil pengamatan hidrologi (SPAS), hal ini didasarkan pada hasil perhitungan total volume runoff terprediksi (Q-SCS) pada kejadian hujan sebasar maksimum $=108 \mathrm{~mm}$ pada tanggal 20 Desember 2005.

2. Metode Rasional ( $q$-rasional) terjadi over estimate sebesar 49,96\% dalam memprediksi debit aliran puncak pada DAS Keduang dibandingkan dengan nilai aktualnya yang diperoleh dari hasil pengamatan hidrologi (SPAS), hal ini didasarkan pada hasil perhitungan debit maksimum terprediksi ( $q$-rasional) pada kejadian hujan maksimum $=108$ $\mathrm{mm}$ dan tinggi muka air maksimum $=$
3,30 m pada tanggal 20 Desember 2005

3. Metode MUSLE (A-MUSLE) terjadi over estimate sebesar 48,47\% dalam memprediksi erosi tanah pada DAS Keduang, dibandingkan dengan nilai aktualnya yang diperoleh dari hasil pengamatan hidrologi (SPAS) tahun 2005. Perhitungan hasil erosi tanah (A) dari MUSLE terprediksi (A-MUSLE) di DAS Keduang tahun 2005 sebesar 158,2610 ton/ha/th dibandingkan dengan nilai aktualnya yang diperoleh dari hasil pengamatan hidrologi (SPAS) tahun 2005 nilainya sebesar 106,5931 ton/ha/th, sehingga terjadi penyimpangan sebesar $+51,6679$ ton $/$ ha/th $(48,47 \%)$.

4. Estimasi volume limpasan permukaan dengan model SCS, estimasi debit puncak aliran dengan model Rasional (qp-rasional) dan metode perhitungan erosi tanah dengan model MUSLE (AMUSLE) pada DAS Keduang dengan luas yang relatif besar (42.644 ha) terjadi over estimate apabila dibandingkan dengan hasil pengukuran aktual.

5. Disarankan perlu untuk dilaksanakan lagi penelitian pada lokasi lain yang mempunyai variasi luasan DAS yang berbeda-beda.

\section{DAFTAR PUSTAKA}

Abdulrachman, A.,S. Abujamin, and U.Kurnia. 1984. Soil and Management Practices For Erosion Control. In Lal, R.1990, Soil Erosion in The Tropics Principles and Management, Mc Graw - Hill, Inc., New York.

Arsyad, S. 1989. Soil and Water Conservation (translated). IPB Press, Bogor, Indonesia.

Bols, P.L. 1978. The Iso-Erodent Map of Java and Madura. SRI, Bogor. 
Coursey, D.G., J.C. Shaake, and E.H. Seely. 1982. Stochastic Models in Hydrology. In Haan, Johnson, Brakensiek (Ed): Hydrologic Modelling of Small Watersheds. ASAE Monograph : $19-73$.

De Roo, A.P.J. 1993. Modelling Surface Run Off and Soil Erosion in Catchments Using Geographical Information System. Nederlands Geografishche Studies 157. Utrecht.

Fleming, 1979. Deterministic Models in Hydrology. FAO. Rome. Italy.

Junun Sartohadi dan Ratih Fitria Putri. 2008. "Evaluasi Potensi Degradasi Lahan dengan Menggunakan Analisa Kemampuan Lahan dan Tekanan Penduduk terhadap Lahan Pertanian di Kecamatan Kokap Kabupaten Kulon Progo" dalam Forum Geografi, Vol. 22, No. 1, Juli 2008. Hlm. 1-12.

Kurnia, U. and H.Suwardjo. 1985. Effect of Mechanical Conservation Methods on Soil in Tropoudulf and Tropothent in Yogyakarta. In Lal, R. (1990), Soil Erosion In The Tropics : Principles and management, Mc.Graw-Hill, Inc., New York.

Mc.Cool, D.K., L.C. Brown, G.R. Foster, C.K. Mutchler, and L.D. Meyer. 1987. Resived Slope Steepness Factor for The USLE. Trans ASAE., 30 (5): 1397-1396.

Mc.Cuen,R.H. 1989. Hydrologic Analysis and Design. Prince Hall, New York.

Seyhan, E. 1977. Mathematical Simulation of Watershed Hydrologic Processes. Geografisch Instituut der Rijksununiversiteit te Utrecht, Utrecht.

Sharp, J.J. and P.G. Sawden. 1984. Basic Hydrology. Butterworth \& Co., London.

Sosrodarsono, S. 1978. Hidrologi Untuk Pengairan. PT Pradnya Paramita. Jakarta.

Sudariyono, 1984. Pengelolaan Daerah Aliran Sungai. Seminar Hidrologi Dalam Rangka Peringatan Dies Natalis XXXV, Fakultas Geografi Universitas Gadjah Mada. Yogyakarta 14-15 Desember 1984

Suprapto Dibyosaputro. 2005. "Muatan Suspensi Total dan Laju Sedimentasi Sungai Kayan di Kabupaten Bulungan, Kalimantan Timur". Forum Geografi, Vol. 19, No. 2, Desember 2005. Hlm. 115-126.

Sukresno. 1999. Laporan Kajian Penerapan RUSLE, MUSLE Untuk Pendugaan Erosi dan Sedimentasi. BTPDAS, Badan Litbang Kehutanan dan Perkebunan, Dephutbun, Surakarta.

Wischmeier,W.H. dan D.D. Smith. 1978. Predicting Rainfall Erosion Losses - A Guide To Conservation Planning. USDA. Ag. Handbook No.537, 58 p. 